\title{
Taste Masked Oral Fast Dissolving Sublingual Strips of Rizatriptan Benzoate for Migraine Therapy
}

\author{
Kailas K. Mali, Remeth J. Dias, Vishwajeet S Ghorpade, Vijay D Havaldar, Bhimrao K. Rupnoor, Nikhil S Dhane
}

\begin{abstract}
The aim of present investigation was to develop a taste masked fast dissolving sublingual strips of rizatriptan benzoate. The fast dissolving strips (FDS) were prepared by solvent casting method using polyox N-10 and polyethylene glycol 400 (PEG 400) as polymer and plasticizer respectively. The FDS were evaluated for $\mathrm{pH}$, folding endurance, tensile strength, moisture absorption, disintegration time and in vitro dissolution. All formulations were free from bubble and exhibited smooth appearance. The $\mathrm{pH}$ of the films was acidic. It was observed that increase in the concentration of polyox N-10 increased the disintegration time but reduced the dissolution rate. The formulation A2 showed all the evaluation parameters within the acceptable range and was considered as optimized
\end{abstract}

formulation. The optimized formulation was subjected to the taste masking and stability study. The results of taste masking study indicated an efficient masking of the bitter taste of drug by the flavouring agents in the film. The formulation A2 was found to be stable for three months with an insignificant change in the drug content and mean dissolution time (MDT). The compatibility study performed using ATR-FTIR and DSC analysis indicated absence of any unusual interaction between drug and excipients used in formulation. Thus, the FDS comprised of polyox N-10 and PEG 400 may be a better alternative to the other available fast dissolving systems for delivery of rizatriptan benzoate.

Keywords: Fast dissolving strips, Polyox N-10, PEG 400, Rizatriptan benzoate
Kailas K. Mali, Remeth J. Dias, Vishwajeet S Ghorpade, Vijay D Havaldar, Bhimrao K. Rupnoor, Nikhil S Dhane

Department of Pharmaceutics, YSPM'S Yashoda Technical Campus, Faculty of Pharmacy, Wadhephata, Satara 415011, India.

Corresponding Author:

Kailas K. Mali

e-mail:malikailas@gmail.com

Submitted / Gönderilme: 22.10 .2016

Accepted / Kabul: 04.01.2017
Revised / Düzeltme: 31.12.2016

\section{INTRODUCTION}

Migraine is a severe neurological disorder which affects around $12 \%$ of the worldwide population. It can cause severe throbbing pain or pulsing sensation on one side of the head. In some patients, a migraine attack may cause nausea and vomiting (1). In the United States, more than $28 \%$ people are suffering from migraine headache(2). The triptans and nonsteroidal anti-inflammatory drugs have been found to provide a symptomatic relief in migraine (3). Rizatriptan benzoate is a selective 5-hydroxytriptamine $(5-\mathrm{HT}) 1 \mathrm{~B} / 1 \mathrm{D}$ receptor agonist which is used for the acute treatment of migraine in adults with or without aura(4). Although it is a cost effective oral triptan available for the treatment of migraine, it suffers from some drawbacks such as poor oral bioavailability due to an extensive first-pass effect and the bitter taste (5). Due to this reason, rizatriptan benzoate is available in the market as an orodispersible tablet.

Orodispersible tablets (ODTs) may prevent the hepatic and gut-wall first pass metabolism by allowing the drug to be absorbed from the upper GI tract into the systemic circulation. 
Besides, the ODTs may avoid choking during administration and the flavoring agents used in these tablets may mask the unpleasant taste of the bitter drug. This may help to improve the patient compliance (6). Nonetheless, these tablets also suffer from some drawbacks. The disintegrated materials from the ODTs usually remain undissolved until swallowed which may cause an unpleasant feeling in the oral cavity (7). On the other hand, problems related to the friability may arise during the handling, transportation, and storage of the ODTs due to their high porosity, low mechanical strength and low density (8). These drawbacks of the ODTs can be overcome using fast dissolving sublingual strips (FDSSs)(9).

Research and development in the oral drug delivery field has led to transition of dosage forms from simple conventional tablets/capsules to the development of oral thin strips(10). Based on technology of transdermal patch, oral strips were developed which consists of a very thin strip that can be placed on the patient's tongue. The strip rapidly hydrates when it comes in contact with saliva and quickly absorbed in the systemic circulation. The strip offers advantages like convenience of dosing and portability that leads to its wider acceptability by pediatric as well as geriatric patients (11). The sublingual strips are now gaining the importance in the treatment of migraine as it helps to avoid the first pass metabolism of the drug and promotes rapid onset of pharmacological action (1).

Many coworkers have prepared thin oral film by using natural polymers such as pullulan, xanthan(12), and synthetic polymers like hydroxypropylmethylcellulose(13), polyvinyl pyrrolidone(14), etc(15). Polyox N-10 is a well known film forming polymer widely used as a binding agent for tablets, granules, pellets, etc. The film forming ability of the polymer depends on its nature and concentration (16).

Considering the above facts, the present investigation aims to formulate taste masked FDDS of rizatriptan benzoate using polyox N-10 (film forming agent) for migraine therapy and to study the effect of formulation variables on the properties of FDSSs.

\section{MATERIALS AND METHODS}

\subsection{Materials}

Rizatriptan benzoate was obtained as a gift sample from Cipla Ltd. Kurkumnbh, Pune, India. Polyox N-10 was gifted from Colorcon Asia Pvt. Ltd., Goa. Sucralose and strawberry flavor were received as a gift sample from Okasa Pharma, Satara.
Polyethylene glycol 400 (PEG 400) and other analytical grade chemicals were purchased from Loba Chemie, Mumbai, India.

\subsection{Preparation of oral fast dissolving strips of Rizatriptan benzoate}

The fast dissolving strips of rizatriptan benzoate were prepared by solvent casting method. In brief, PEG 400 (plasticizer) and the polyox N-10 were dissolved in the water by stirring on magnetic stirrer (Remi, India). The stirring was continued for $4 \mathrm{~h}$ and the solution was kept aside for $1 \mathrm{~h}$ to remove the entrapped air bubbles. Meanwhile, in the separate container, a solution of other water soluble ingredients such as sucralose and citric acid was prepared followed by addition of menthol, strawberry and Tween 80 with constant stirring for $45 \mathrm{~min}$. Both the solutions were mixed together and stirred for $1 \mathrm{~h}$. The mixture was kept stationary to settle the foam. Finally, the mixture was casted on a suitable inert platform $\left(44.15 \mathrm{~cm}^{2}\right)$ and dried to form thin film. The film was tested for any imperfections and strips were cut according to the size required $(2.5 \mathrm{x}$ $2.5 \mathrm{~cm})(11)$. The formulation codes and their respective compositions are given in table 1 .

Table 1. Formulations of oral fast dissolving strips containing polyox $\mathrm{N}-10$

\begin{tabular}{lccccccc}
\hline Ingredients & A1 & A2 & A3 & A4 & A5 & A6 & A7 \\
\hline Polyox N-10 & 4 & 6 & 8 & 10 & 12 & 6 & 6 \\
PEG-400 & 4 & 4 & 4 & 4 & 4 & 2 & 6 \\
Sucralose & 0.5 & 0.5 & 0.5 & 0.5 & 0.5 & 0.5 & 0.5 \\
Citric acid & 1 & 1 & 1 & 1 & 1 & 1 & 1 \\
Menthol & 0.5 & 0.5 & 0.5 & 0.5 & 0.5 & 0.5 & 0.5 \\
Strawberry & 0.25 & 0.25 & 0.25 & 0.25 & 0.25 & 0.25 & 0.25 \\
Tween 80 & 0.5 & 0.5 & 0.5 & 0.5 & 0.5 & 0.5 & 0.5 \\
Rizatriptan benzoate & 5 & 5 & 5 & 5 & 5 & 5 & 5 \\
Water & q.s & q.s & q.s & q.s & q.s & q.s & q.s \\
\hline
\end{tabular}

All ingredients in $\% \mathrm{w} / \mathrm{v}$

\subsection{Weight of strips}

Oral fast dissolving strips were weighed on analytical single pan balance (AX 120, Shimadzu, Japan) (17).

\subsection{Thickness of strips}

The thickness of strips was measured by using a micrometer screw gauge (10). 


\subsection{Folding endurance of strips}

Folding endurance of the strips was measured manually. A strip was repeatedly folded at the same place till it breaks. The number of times the strip could be folded at the same place without breaking gives the folding endurance of the strip (18). The folding endurance also gives an idea about brittleness of the film.

\subsection{Tensile Strength of strips}

Tensile strength is the maximum stress required to break the strip. In this test, the strip was tied between two clamps and one end of clamp was directly attached to pan through pulley. The strips were subjected to stress by adding load to the pan. The load was increased until the film breaks (failure). The minimum load required for breaking the film (load at failure) was noted (10). It is calculated by the following formula,

Tensile strength $=\frac{\text { Load at failure } \times 100}{\text { Strip thickness } \times \text { Strip width }}$

\section{$2.7 \mathrm{pH}$ of strips}

The $\mathrm{pH}$ of the FDSSs was determined by dissolving each oral strip in $5 \mathrm{ml}$ distilled water and measuring the $\mathrm{pH}$ of the solution with the help of $\mathrm{pH}$ meter (Systronic, India) (19).

\subsection{Moisture absorption study}

Moisture absorption capacity of the strips was determined according to the previously reported method (17). The pre-weighed strips were placed in a desiccator at room temperature. After $72 \mathrm{~h}$, the strips were removed from the desiccator and exposed to $75 \%$ relative humidity by using humidity chamber (Bio-Technics, India). The moisture uptake was measured as percent increase in the weight of the strip using following formula:

Percent moisture absorption $=\frac{\text { Final weight }- \text { Initial weight }}{\text { Initial weight }}$

\subsection{Content Uniformity}

Drug content was determined by dissolving the strip containing $5 \mathrm{mg}$ of drug in $100 \mathrm{ml}$ phosphate buffer $(\mathrm{pH}$ 6.4). An aliquot equivalent to $2 \mathrm{ml}$ was suitably diluted and analyzed using UV- spectrophotometer (UV-1800, Shimadzu, Japan) at $225 \mathrm{~nm}$. The measurements were done against blank solution prepared by using dummy strip treated in same manner.

\subsection{Disintegration time of strips}

The disintegration time of strips was determined by using disintegrating test apparatus (Electrolab, India). The disintegrating test was carried out in $900 \mathrm{ml}$ phosphate buffer $\mathrm{pH} 6.4$ at $37 \pm 0.5^{\circ} \mathrm{C}(10)$. Time required to disintegrate the strip was recorded. The measurements were done in triplicate.

\subsection{In Vitro Dissolution Studies}

The in vitro dissolution study for the FDSSs and marketed ODT of rizatriptan benzoate was carried out in $900 \mathrm{ml}$ phosphate buffer ( $\mathrm{pH}$ 6.4) using USP dissolution type II apparatus at $37 \pm 0.5^{\circ} \mathrm{C}$ (stirring speed $=50 \mathrm{rpm}$ ). The strip was submerged into the dissolution media and appropriate aliquots were withdrawn at predetermined time intervals. The samples were analyzed spectrophotometrically (UV1800, Shimadzu, Japan) at $225 \mathrm{~nm}$. Sink conditions were maintained throughout the experiment $(10,17)$. The same procedure was repeated for the marketed ODT (Rizact$5 \mathrm{MD})$. The dissolution test was performed in triplicate.

\subsection{Stability Studies}

The strips were wrapped in aluminum foil and subjected to stability test at temperature $40^{\circ} \mathrm{C}$ with relative humidity of 75\% RH (Bio-Technics, India). The strips were withdrawn after 90 days and evaluated for weight, thickness, folding endurance, tensile strength, disintegration time, drug content and in vitro dissolution. The in vitro dissolution data of the optimized formulation before and after stability studies was compared using similarity factor, $f_{2}$. The formulation before stability studies was considered as reference formulation whereas formulation after stability studies was considered as test formulation (17). Dissolution profiles were considered as similar if $f_{2}$ value lied between 50-100(20).

\subsection{Evaluation of Taste}

In order to achieve patient compliance, taste masking is necessary for the fast dissolving systems containing bitter drug. Taste of the formulation A2 was evaluated by time intensity method using a panel of human volunteers (21). For this purpose, nine healthy human volunteers were selected 
and strip was held in the volunteer's mouth. Bitterness level was recorded immediately at 15, 30, 60, 90, and 120 seconds. Bitterness values were rated by giving different values as mentioned below:

00- Sweet; 0- Slightly sweet; 1-No bitterness and 2- Bitter

\subsection{Compatibility study}

The compatibility in between drug and formulation excipients was determined using attenuated total reflectance-fourier transform infrared (ATR-FTIR) spectroscopy and differential scanning calorimetry (DSC). An ATR-FTIR spectrum of rizatriptan benzoate and formulation was recorded by using ATR-FTIR (Alpha E, Bruker, Japan) Spectrophotometer. The samples to be analyzed were transferred to the ATR compartment. The spectra were obtained for the range of $600-4000 / \mathrm{cm}$ at an average of 25 scans and resolution of 4/ $\mathrm{cm}$. Differential scanning calorimetry (DSC) thermogram of the pure drug, physical mixture of pure drug and Polyox $\mathrm{N}-10$ (1:1) and optimized strip formulation were recorded on a thermal analyzer (DSC 823e, Mettler Toledo, Melbourne, Australia). The samples were heated at the rate of $10^{\circ} \mathrm{C} / \mathrm{min}$ in an inert nitrogen atmosphere. The heating was carried out in the temperature range of 30 to $300^{\circ} \mathrm{C}$.

\section{RESULTS AND DISCUSSION}

\subsection{Weight of strips}

The average weight of respective formulations is given in table 2 . The weight of strips was found to be in the range of $41 \pm 1.00 \mathrm{mg}$ to $74.3 \pm 1.52 \mathrm{mg}$. The difference in the average weight of all formulations may be due to change in excipients, their nature and concentration. It was observed that weight of films increased with increase in the polymer concentration.

\subsection{Thickness of strips}

The thickness of strips was found to be in between $30 \mathrm{~mm}$ to $80 \mathrm{~mm}$ (table 2). The thickness was measures at three different regions of the film. The low value of standard deviation indicates that the variation in the weight of the films did not affect the mass uniformity. An increase in the polymer concentration from 4 to $12 \%$, increased the thickness of the FDSSs possibly due to increase in the polymer bulk.

\subsection{Folding endurance of strips}

The folding endurance of all prepared strips was found to be in the range of $37 \pm 3.51$ to $209 \pm 2$ (table 2). The folding endurance of FDSSs was found to be decrease with increase in the polymer concentration. The increase in the polymer concentration may reduce the flexibility of the strips leading to decrease in its folding endurance. An increase in the folding endurance associated with increase in the concentration of PEG 400 can be attributed to the interference of the PEG with the glass transition temperature of the polymer within the strip. Such interference of the plasticizer may decrease the melting point of the polymer and enhance its flexibility, thus increasing folding endurance of the strips(22).

\subsection{Tensile strength of strips}

The FDSSs exhibited the tensile strength in the range of $138.8 \pm 3.8$ to $340.8 \pm 1.4 \mathrm{Kg} / \mathrm{cm}^{2}$ (table 2 ). An increase in the concentration of PEG 400 reduced the tensile strength of the strips possibly due to decrease in the rigidity. The addition of plasticizer leads to the formation of a more porous and less dense polymer structure due to which, the strip breaks at lesser force(22).On the other hand, increase in the polymer concentration increased the tensile strength of the strips. This may be due to the formation of densely packed network of Polyox N-10 chains at higher concentration.

Table 2. Evaluation of oral fast dissolving strips of rizatriptan benzoate

\begin{tabular}{ccccc}
\hline Formulations & $\begin{array}{c}\text { Wt. of strips } \\
(\mathbf{m g})(\mathbf{n}=\mathbf{3})\end{array}$ & $\begin{array}{c}\text { Thickness } \\
(\mathbf{m m})(\mathbf{n}=\mathbf{3})\end{array}$ & $\begin{array}{c}\text { Folding Endurance } \\
(\mathbf{n}=\mathbf{3})\end{array}$ & $\begin{array}{c}\text { Tensile strength } \\
\left(\mathbf{k g} / \mathbf{c m}^{2}\right)(\mathbf{n}=\mathbf{3})\end{array}$ \\
\hline A1 & $41 \pm 1.0$ & $30 \pm 0.52$ & $177 \pm 2.0$ & $138.8 \pm 3.8$ \\
A2 & $45 \pm 1.0$ & $33.3 \pm 0.5$ & $157 \pm 3.21$ & $186 \pm 3.2$ \\
A3 & $53.3 \pm 2.5$ & $50.0 \pm 1.5$ & $138 \pm 2.16$ & $241.3 \pm 2.3$ \\
A4 & $61 \pm 2.0$ & $70 \pm 1.0$ & $109 \pm 3.3$ & $283.5 \pm 1.8$ \\
A5 & $74.3 \pm 1.5$ & $80 \pm 0.52$ & $37 \pm 3.51$ & $340.8 \pm 1.4$ \\
A6 & $43 \pm 2.0$ & $36.6 \pm 1.1$ & $83 \pm 2.00$ & $198.3 \pm 2.8$ \\
A7 & $47.3 \pm 2.0$ & $40 \pm 1.0$ & $209 \pm 2.00$ & $170.0 \pm 1.0$ \\
\hline
\end{tabular}

Values are expressed as mean \pm standard deviation 


\section{$3.6 \mathrm{pH}$ of strips}

The $\mathrm{pH}$ of FDSSs ranged from $5.4 \pm 0.10$ to $6.1 \pm 0.05$ (table 3 ). The $\mathrm{pH}$ was found to be acidic due to the presence of citric acid. As the observed $\mathrm{pH}$ values of strips were close to the buccal $\mathrm{pH}$, the chances of irritation to the mucosal lining of oral cavity was negligible(7). The difference in $\mathrm{pH}$ values of the strips may be due to differences in excipients used in formulations.

\subsection{Moisture absorption study}

The moisture absorption study gives an idea about the stability of strips. The strip will be less stable if it has more absorption property. The results of moisture absorption study are given in the table 3 .

It was observed that, the moisture absorption of the strip was increased with increase in the concentration of polymer as well as plasticizer. This may be due to hydrophilic nature of polymer and plasticizer.

\subsection{Drug content}

The drug content was found to be in between $93.1 \pm 1.49$ to $99.8 \pm 0.10 \%$ (table 3 ) indicating uniform distribution of drug in the strips.

\subsection{Disintegration time of strips}

The disintegration time of FDSSs is shown in table 3. It was observed that increase in the polymer concentration increased the disintegration time of the strips. This may be due to the formation of viscous gel layer at high polymer concentration that prevents intimate contact between the particles of polymer. The mobility of drug particles in swollen matrices decreases thus increasing disintegration time(23). When PEG 400 concentration was increased, the disintegration time was found to be decreased which may be ascribed to its hydrophilic nature.

\subsection{In Vitro Dissolution studies}

Dissolution studies of FDSSs and marketed tablet formulation (MF) of rizatriptan benzoate was carried out using phosphate buffer $\mathrm{pH}$ 6.4. Figure 1 displays the drug release profile of FDSSs and MF. The FDSSs released nearly $75.2-100.2 \%$ drug within 6 minutes. Although, the difference in the release rate for formulations A1-A3, A6 and A7 was insignificant, these formulations showed fast release as compared to the MF. As the concentration of polyox N-10 was increased from $4-12 \%$, the amount of drug release was found to be decreased. This may be due to increase in the formation of viscous gel layer around the surface of strip that decreases the mobility of drug particles and reduces the release rate(23). The values of the MDT for FDSSs and MF are given in table 3. The release rate and MDT of formulations A1 and A2 was close to each other, however, the tensile strength of A2 was better. Therefore, formulation A2 was considered as an optimized FDSS.

Table 3. Evaluation of oral fast dissolving strips of rizatriptan benzoate

\begin{tabular}{|c|c|c|c|c|c|}
\hline Formulations & $\begin{array}{l}\text { Moisture absorption } \\
\text { study } \\
(\mathbf{n}=3)\end{array}$ & $\begin{array}{l}\text { Disintegration time } \\
\quad(\sec )(n=3)\end{array}$ & $\begin{array}{c}\mathrm{pH} \text { Value } \\
\quad(\mathrm{n}=3)\end{array}$ & Drug content (\%) & $\begin{array}{l}\text { Mean dissolution time } \\
(\mathrm{MDT})(\mathrm{min})\end{array}$ \\
\hline $\mathrm{A} 1$ & $2.43 \pm 0.14$ & $6.0 \pm 0.05$ & $6.0 \pm 0.05$ & $97.3 \pm 1.48$ & 0.52 \\
\hline A2 & $5.82 \pm 0.11$ & $10.3 \pm 0.11$ & $6.1 \pm 0.05$ & $99.8 \pm 0.10$ & 0.56 \\
\hline A3 & $10.29 \pm 1.14$ & $13 \pm 0.05$ & $5.9 \pm 0.10$ & $95.5 \pm 0.92$ & 0.64 \\
\hline A4 & $12.90 \pm 0.65$ & $18 \pm 0.08$ & $5.7 \pm 0.05$ & $93.1 \pm 1.49$ & 0.93 \\
\hline A5 & $15.38 \pm 0.14$ & $61.3 \pm 0.05$ & $5.4 \pm 0.10$ & $94.8 \pm 0.70$ & 1.23 \\
\hline A6 & $3.17 \pm 0.31$ & $11.3 \pm 0.10$ & $6.1 \pm 0.05$ & $98.0 \pm 0.64$ & 0.59 \\
\hline A7 & $7.51 \pm 0.20$ & $9.0 \pm 0.15$ & $6.0 \pm 0.10$ & $93.1 \pm 1.49$ & 0.61 \\
\hline MF & - & - & - & & 0.74 \\
\hline
\end{tabular}

Values are expressed as mean \pm standard deviation 


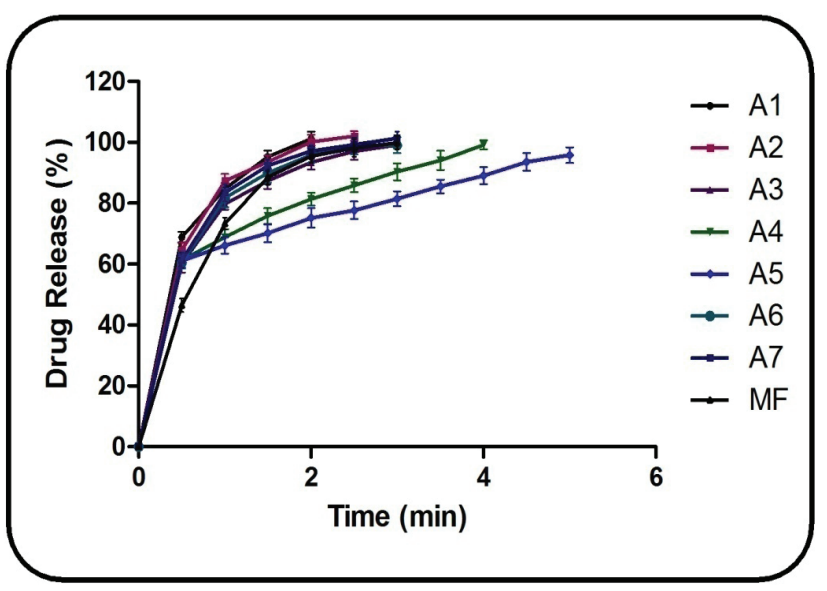

Figure 1. Drug release profile of formulations A1 to A7 and marketed formulation (MF)

\subsection{Stability Studies}

The stability study of optimized formulation A2 was carried out at $40^{\circ} \mathrm{C}$ with $75 \%$ relative humidity for the period of three months. Table 4 shows the parameters of formulation A2 before and after the stability study. No significant change was noticed in the parameters of A2 after the stability study. The drug release profile A2 before and after the stability study is displayed in figure 2 . The value of $f_{2}$ after 90 days was found to be 80.98 whereas the difference factor $\left(f_{1}\right)$ value was found to be 2.44. This indicates that the release profile of the formulation A2 was not markedly affected by the changes in the temperature and humidity.

Table 4. In vitro parameters of batch A2 before and after stability study

\begin{tabular}{lcc}
\hline Parameter & $\begin{array}{c}\text { Before stability } \\
\text { study }(\mathbf{n}=\mathbf{3})\end{array}$ & $\begin{array}{c}\text { After stability study } \\
(\mathbf{n}=3)\end{array}$ \\
\hline Weight of strip $(\mathrm{mg})$ & $45 \pm 1.0$ & $46.33 \pm 0.85$ \\
Thickness of strip $(\mu \mathrm{m})$ & $33.3 \pm 0.57$ & $33.9 \pm 0.51$ \\
Folding endurance & $157 \pm 3.21$ & $154 \pm 1.56$ \\
Tensile strength $\left(\mathrm{kg} / \mathrm{cm}^{2}\right)$ & $186 \pm 3.2$ & $182.5 \pm 2.80$ \\
Disintegration Time $(\mathrm{sec})$ & $10.3 \pm 0.11$ & $10.8 \pm 1.08$ \\
Drug content $(\%)$ & $99.8 \pm 0.1$ & $99.1 \pm 0.42$ \\
Drug release at the end of & $100.2 \pm 1.19$ & $98.1 \pm 1.37$ \\
2 min $(\%)$ & & \\
\hline
\end{tabular}

Values are expressed as mean \pm standard deviation

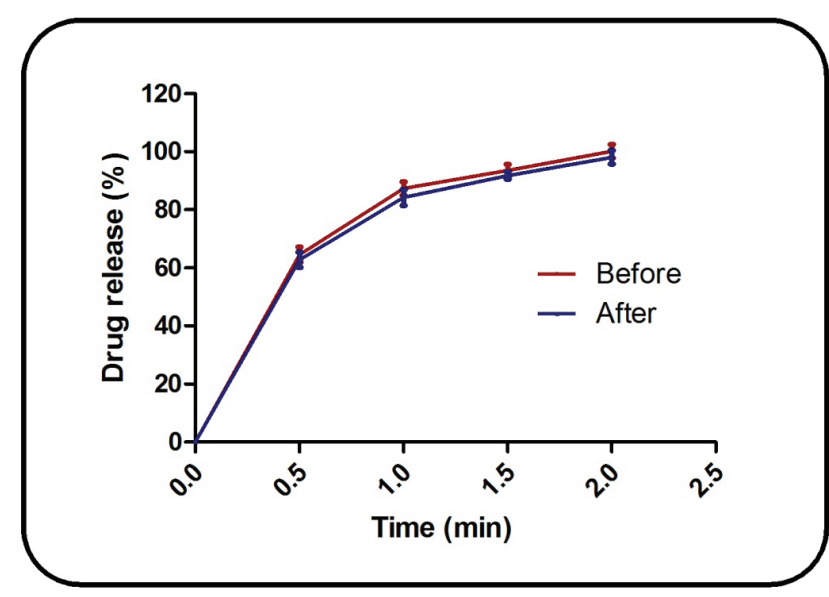

Figure 2. Drug release profile of formulation A2 before and after stability study

\subsection{Evaluation of taste}

In the study of taste assessment of formulation A2, a panel of nine individuals was used and the volunteers were asked to assess the taste in general as well as taste in particular. Four criteria were used in assessing the taste: bitter, not bitter, slightly sweet, and sweet. It was observed that at $15^{\text {th }} \mathrm{sec}$, the slight sweetness was sensed by most of the volunteers. The strip showed no bitterness up to $120 \mathrm{sec}$. This makes it clear that efficient taste masking was achieved for FDSSs.

Table 4. Observations of taste masking of A2 after different time intervals

\begin{tabular}{cccccc}
\hline \multirow{2}{*}{ Volunteers } & \multicolumn{5}{c}{ Taste level after } \\
\cline { 2 - 6 } & $\mathbf{1 5 s e c}$ & $\mathbf{3 0 s e c}$ & $\mathbf{6 0 s e c}$ & $\mathbf{9 0 s e c}$ & $\mathbf{1 2 0 s e c}$ \\
\hline $\mathbf{1}$ & 0 & 0 & 1 & 1 & 1 \\
$\mathbf{2}$ & 0 & 0 & 1 & 1 & 1 \\
$\mathbf{3}$ & 0 & 1 & 1 & 1 & 1 \\
$\mathbf{4}$ & 0 & 0 & 1 & 1 & 1 \\
$\mathbf{5}$ & 0 & 0 & 1 & 1 & 1 \\
$\mathbf{6}$ & 0 & 1 & 0 & 1 & 1 \\
$\mathbf{7}$ & 0 & 0 & 1 & 1 & 1 \\
$\mathbf{8}$ & 0 & 0 & 1 & 1 & 1 \\
$\mathbf{9}$ & 0 & 1 & 1 & 1 & 1 \\
\hline
\end{tabular}

00- Sweet, 0-Slightly sweet, 1 -No bitterness and 2- Bitterness 


\subsection{Compatibility study}

The IR spectra of pure rizatriptan benzoate (Figure 3A), polyox N-10 (figure 3B) physical mixture of rizatriptan benzoate (figure 3C), and formulation A2 (figure 3D) are shown in figure 4 . The IR spectrum of pure rizatriptan benzoate showed characteristic peaks at 725, 1379.40, 1565.59, 1606.11 and $2881.62 \mathrm{~cm}^{-1}$, indicating rocking (medium stretching) of $\mathrm{N}-\mathrm{H}$ in triazole, $\mathrm{N}-\mathrm{H}$ bending in indole, $\mathrm{C}=\mathrm{N}$ stretching in triazole, $\mathrm{C}=\mathrm{O}$ stretching in aryl ester and $\mathrm{C}-\mathrm{H}$ stretching respectively. These peaks were observed almost at the same wave number with the same intensity in the spectra of physical mixtures and formulation A2. Also, no extra peak was observed in IR spectrum of physical mixtures and formulations which indicate the absence of any potential physical or chemical interaction between the drug, polymer and other formulation additives. Thus, the formulation excipients were found to be compatible with the drug.

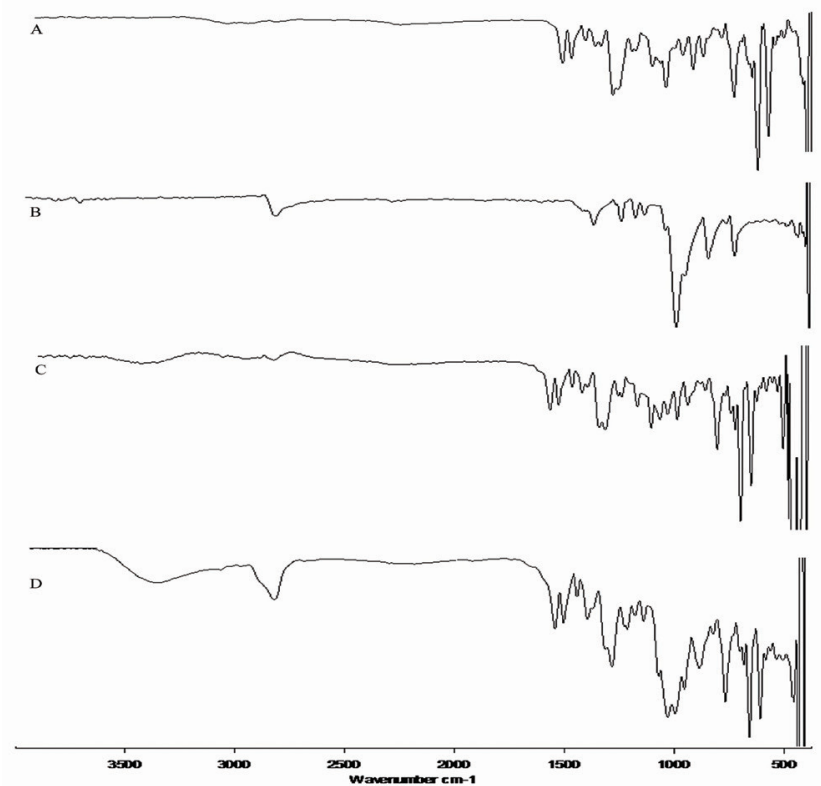

Figure 3. Overlay IR spectra of (A): Rizatriptan benzoate, (B): Polyox N-10 (C): Drug and Polyox N-10 (1:1) physical mixture, (D): Formulation A2

The supporting evidence for compatibility between drug and excipients was also obtained from DSC analysis (Figure 4). The DSC thermogram of rizatriptan benzoate (figure 4A) showed a sharp endothermic peak at $180.45^{\circ} \mathrm{C}$ which corresponds to the melting point of pure drug. DSC thermogram of physical mixture (figure $4 \mathrm{~B}$ ) and optimized formulation, A2 (figure
4C) showed slight broad endothermic peak at $179.81^{\circ} \mathrm{C}$ and $179.0^{\circ} \mathrm{C}$ respectively. The DSC thermogram of formulation showed non-significant shift in endothermic peak of rizatriptan benzoate, along with reduction in peak height. This may be due to molecular dispersion of drug in polymer matrix. The absence of additional peaks in the thermogram of formulation indicates the lack of unusual interactions between drug and formulation excipients.

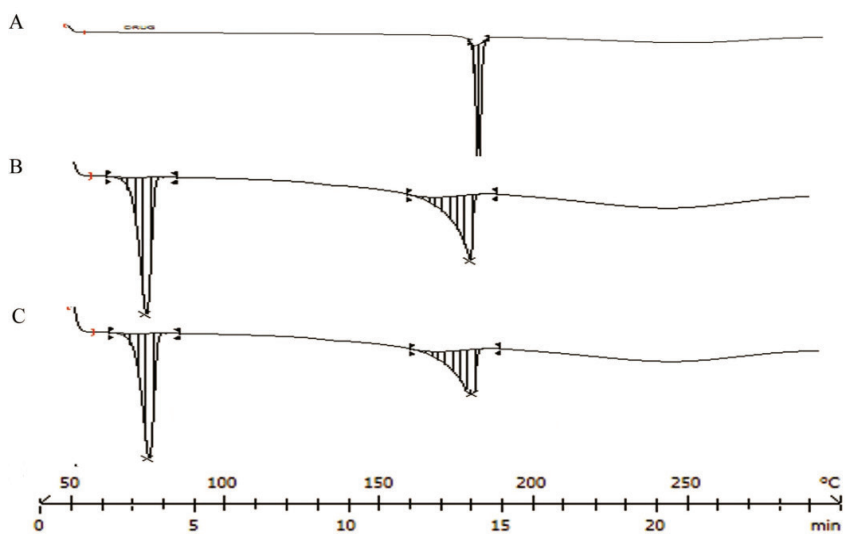

Figure 4. Overlay DSC thermograms (A) Rizatriptan benzoate, (B) Drug and Polyox N-10 (1:1) physical mixture, (C) Formulation A2

\section{CONCLUSION}

The FDSSs of rizatriptan benzoate were prepared using polyox $\mathrm{N}-10$ as a strip forming materials by solvent casting method. Formulation variables like amount of polyox $\mathrm{N}-10$, amount of plasticizer (PEG 400) were found to have influence on thickness, folding endurance, tensile strength, moisture absorption, in vitro disintegration time and in vitro dissolution of the strips. The FDSSs were found to be thin and showed fast disintegration, satisfactory dissolution and acceptable physico-mechanical characteristics. The bitter taste of rizatriptan benzoate could be successfully masked by using combination of sucralose and strawberry flavor. The stability study of strip A2 showed no significant $(p<0.05)$ difference between in vitro drug release, disintegration time and physical properties of formulations.

Therefore, the FDSSs containing rizatriptan benzoate is considered to be potentially useful for treatment of migraine where improved patient compliance and convenience is expected. 


\section{ACKNOWLEDGEMENTS}

Authors are thankful to Cipla Ltd, Kurkumbh, Colorcon Asia Pvt. Ltd., Goa and Okasa Pharma, Satara for providing gift samples of rizatriptan benzoate, Polyox N-10 and flavours respectively. Authors are also thankful to Prof. Dasharath

Migren tedavisi için tadı maskelenmiş oral rizatriptan benzoat hızlı çözünen dilaltı stripleri

Öz

$\mathrm{Bu}$ araştırmanın amacı, tadı maskelenmiş rizatriptan benzoat içeren hızlı çözünen dilaltı strip’inin geliştirilmesidir. Hızlı çözünen stripler (Fast Dissolving Strips =FDS) polimer ve plastikleştirici olarak sırasıyla Polyox N-10 and polietilenglikol 400'ün (PEG 400) kullanıldığı çözücü dökme yöntemiyle hazırlanmışlardır. Hızlı çözünen striplerin pH’sı, katlanmaya karşı dayanıklılığı, gerilme kuvveti, nem absorbsiyonu, dağılması ve in vitro çözünmesi incelenmiştir. Tüm formülasyonlar
Sagare, Founder President, YSPM's Yashoda Technical Campus, Satara for providing laboratory facilities.

\section{CONFLICT OF INTEREST}

No conflict of interest

baloncuk içermez ve yumuşak bir görünüş sergiler. Filmlerin pH'sı asidiktir. Polyox N-10 oranı arttıkça dağılma zamanının arttığı fakat serbestleşme hızının azaldığ 1 gözlemlenmiştir. A2 formülasyonu tüm değerlendirme sonuçlarını kabul edilebilir bir aralıkta göstermiştir ve optimize formül olarak düşünülmüştür. Optimize formülasyon tat maskeleme ve stabilite çalışmalarına tabi tutulmuştur. Tat maskeleme çalışmalarının sonuçları, ilacın acı tadının film içindeki tatlandırıcı ajanlar tarafından etkin bir şekilde maskelendiğini göstermiştir.

Anahtar kelimeler: Hızlı çözünen dilaltı stripleri, Polyox N-10, PEG 400, Rizatriptan benzoat

\section{REFERENCES}

1. Pandey P, Chauhan S. Fast dissolving sublingual films of Zolmitriptan: A novel treatment approach for migraine attacks. Indian J Pharm Educ Res 2014;48:67-72.

2. Galletti F, Cupini LM, Corbelli I, Calabresi P, Sarchielli P. Pathophysiological basis of migraine prophylaxis. Prog Neurobiol 2009;89:176-92.

3. Freitag FG, Schloemer F, Shumate D. Recent developments in the treatment of migraine in children and adolescents. J Headache Pain Manag 2016;1:1-8.

4. Láinez MJA. Rizatriptan in the treatment of migraine. Neuropsychiatr Dis Treat 2006;2:247-59.

5. Keny R V, Desouza C, Lourenco CF. Formulation and evaluation of rizatriptan benzoate mouth disintegrating tablets. Indian J Pharm Sci 2010;72:79-85.

6. Kulkarni AP, Khedkar AB, Lahotib SR. Development of oral disintegrating tablet of rizatriptan benzoate with inhibited bitter taste. Am J Sci Res 2012;7:47-57.

7. Kunte S, Tandale P. Fast dissolving strips: A novel approach for the delivery of verapamil. J Pharm Bioallied Sci 2010;2:325-8.

8. Kate L, Pol A, Patravale V. Advantages of oral fast dissolving films [Internet]. Pharmabiz. 2010 [cited 2016 Oct 21]. p. 1. Available from: http://www.pharmabiz.com/NewsDetails. aspx?aid=58417\&sid=9

9. Irfan M, Rabel S, Bukhtar Q, Qadir MI, Jabeen F, Khan A. Orally disintegrating films: A modern expansion in drug delivery system. Saudi Pharm J 2016; 24:537-46.

10. Dixit RP, Puthli SP. Oral strip technology: Overview and future potential. J Control Release 2009;139:94-107.

11. Arya A, Chandra A, Sharma V, Pathak K. Fast dissolving oral films: An innovative drug delivery system and dosage form. Int J ChemTech Res 2010;2:576-83.

12. Sayed S, Ibrahim HK, Mohamed MI, El-Milligi MF. Fastdissolving sublingual films of terbutaline sulfate: Formulation and in vitro/in vivo evaluation. Mol Pharm 2013;10:2942-7.

13. Bhupinder B, Sarita J. Formulation and evaluation of fast dissolving sublingual films of Rizatriptan Benzoate. Int J Drug Dev Res 2012;4:133-43.

14. Hirpara F, Debnath SK, Saisivam S. Optimization \& screening of different film forming polymers and plasticizers in fast dissolving sublingual film. Int J Pharm Pharm Sci 2014;6:412.

15. Chaturvedi A, Srivastava P, Yadav S, Bansal M, Garg G, Sharma PK. Fast dissolving films: a review. Curr Drug Deliv 2011;8:373-80.

16. Shah KR, Chaudhary SA, Mehta TA. Polyox (Polyethylene Oxide) multifunctional polymer in novel drug delivery system. Int J Pharm Sci Drug Res 2014;6:95-101.

17. Dinge A, Nagarsenker M. Formulation and evaluation of fast dissolving films for delivery of triclosan to the oral cavity. AAPS PharmSciTech 2008;9:349-56.

18. Semalty M, Semalty A, Kumar G. Formulation and characterization of mucoadhesive buccal films of glipizide. Indian J Pharm Sci 2008;70:43-8.

19. Mehta DM, Dave DJ, Dadhaniya D V, Shelat PK, Parejiya PB, Barot BS. Application of Box-Behnken design to formulate and optimize multipolymeric fast dissolving film of rizatriptan benzoate. Asian J Pharm 2014;8:35-42.

20. Ma M, Lin R, Liu J. Statistical evaluations of dissolution similarity. Stat Sin 1999;9:1011-27.

21. Bhise K, Shaikh S, Bora D. Taste mask, design and evaluation of an oral formulation using ion exchange resin as drug carrier. AAPS PharmSciTech 2008;9:557-62.

22. Repka MA, Gerding TG, Repka SL, McGinity JW. Influence of plasticizers and drugs on the physical-mechanical properties of hydroxypropylcellulose films prepared by hot melt extrusion. Drug Dev Ind Pharm 1999;25:625-33.

23. Sapkal NP, Kilor VA, Daud AS, Bonde MN. Development of fast dissolving oral thin films of ambroxol hydrochloride: Effect of formulation variables. J Adv Pharm Res 2011;2:102-9. 